\title{
Analisis Curse Theory pada Sumber Daya Alam Migas Bagi Warga Madura
}

\author{
Mohammad Hidayaturrahman ${ }^{\mathrm{a}, 1}$ \\ ${ }^{a}$ Universitas Wiraraja Sumenep, Jawa Timur, Indonesia \\ ${ }^{1}$ hidayatsahabatkita2016@gmail.com
}

Article history:

Received : 2018-01-31

Revised : 2018-06-29

Accepted : 2018-06-30

Keywords:

Public policy

Empowerment

Government

Oil and gas company

Community

Government policies in natural resource management, especially in the oil and gas sector face a lot of problems. However, the government also has a responsibility to improve the life of people affected from oil and gas exploration and production activities. This research was aimed at investigating how the implementation of policies run by the central and local government toward the oil and gas management and community empowerment, especially the community located closely to oil and gas exploration and production activity in Madura, East Java. This research method is phenomenological research using descriptive qualitative approach. Therefore, this study is conducted through direct observation on the object during the research time. The data collection is done through observation and interview. The results of this study revealed that it is needed an integrated step done by the government, vertically, whether central, provincial, district, and village to synchronize oil and gas management and community empowerment programs. By doing so, the ideas and desires to improve the welfare and increase the state income will be realized, especially in focusing corporate and government programs improving citizen' economic and education, whose area becomes the location of oil and gas production.

Copyright () 2018 IAIN Palangka Raya. All rights reserved.

\section{Pendahuluan}

Indonesia adalah negeri yang melimpah akan kekanyaan alam. Kekayaan alamnya terbentang dari Sabang sampai Merauke, terhampar di daratan yang luas, terpendam dalam perut bumi, dan tumbuh di pegunungan yang tinggi. Sumber daya alam (SDA) yang ada di Indonesia dapat dikategorikan menjadi dua, sumberdaya alam yang dapat diperbaharui dan sumberdaya alam yang tidak dapat diperbaharui. Termasuk dalam sumberdaya alam yang dapat diperbaharui adalah hutan, ikan, tanaman perkebunan dan lainnya. Sementara, sumberdaya yang tidak dapat diperbaharui berupa mineral, barang tambang (batubara dan emas), minyak dan gas.

Berbicara mengenai sumberdaya minyak dan gas, Indonesia merupakan negara penghasil migas yang cukup besar. Salah satu diantaranya terletak di Provinsi Jawa Timur, yaitu Madura. Madura merupakan salah satu DOI: 10.23971/jsam.v14i1. daerah penghasil minyak bumi dan gas alam (migas) yang cukup besar di Indonesia. Madura secara administratif terdiri dari 4 kabupaten, yaitu Kabupaten Bangkalan, Sampang, Pamekasan dan Sumenep. Dari ke4 kabupaten tersebut, hanya Pamekasan yang tidak memiliki aktivitas terkait eksploitasi migas. Aktivitas migas di Madura semuanya berlokasi di lepas pantai (offshore) pada jarak 0-4 mil dan 4-12 mil. Berdasarkan data yang dikumpulkan dari SKK Migas dan Kementrian ESDM menyebutkan bahwa pada tahun 2010 lifting gas dari Madura mencapai sekitar 90.06 juta MMBTU, namun pada akhir 2014 jumlah tersebut menurun hingga mencapai 69.61 juta MMBTU atau turun sekitar 19 juta MMBTU. Namun begitu, Madura masih menjadi wilayah penghasil utama gas yang mensupplai industry dan rumah tangga di jawa timur.(12)

Negara-negara yang memiliki kekayaan sumber daya alam yang melimpah seharusnya

W : http://e-journal.iain-palangkaraya.ac.id/index.php/jsam E : Jsam.iainpky@gmail.com 
memiliki pertumbuhan yang cepat, memiliki tingkat kemiskinan yang rendah, dan tingkat kesejahteraan yang tinggi. Namun demikian, terdapat sebuah fenomena di mana Negaranegara yang kaya sumber daya alam cenderung memiliki pertumbuhan ekonomi yang lebih rendah, tingkat kemiskinan yang tinggi dan kesejahteraan yang rendah. Fenomena ini disebut sebagai kutukan sumber daya alam (natural resource curse). Kutukan sumber daya alam adalah suatu kondisi dimana terdapat penurunan kinerja sosial dan ekonomi pada daerah yang memiliki kekayaan sumber daya alam yang melimpah.(4)

Diskusi yang diselenggarakan oleh Melbourne Business School (MBS) bekerja sama dengan Center for the Study of Governance (CSG) Universitas Indonesia. Mark Crosby - panelis dari MBS menyebutkan beberapa faktor penyebab kegagalan pengurus sumber daya alam (SDA) yang menyebabkan kehancuran ekonomi Negara, bahkan menciptakan disintegritas sosial pada Negara itu. Dari tiga faktor yang disebutkan, salah satu faktor penyebab yang menarik untuk direfleksikan pada situasi saat ini adalah lemahnya institusi Negara di dalam mengelola SDA yang dimiliki. Lemahnya institusi Negara ditandai dengan tingginya praktik korupsi di dalam pengurusan sumber daya alam. Situasi tersebut berdampak negatif dan dapat beresiko menimbulkan kutukan sumber daya alam bagi perekonomian Indonesia.(11)

Berdasarkan fakta di atas, penelitian ini bertujuan untuk menganalisis kebijakan pemerintah pada pengelolaan sumber daya alam (natural resources), khususnya pada industri minyak bumi dan gas alam (migas) di Madura serta bagaimana pengelolaan kebijakan terhadap pengembangan sumber daya manusia (human resources development) yang ada di Madura.

\section{Kajian Pustaka}

\section{Sejarah Eksplorasi Sumber Daya Alam Indonesia}

Sejarah pencarian minyak dan gas bumi di Indonesia sudah dilakukan sejak zaman kolonial Hindia Belanda hingga sekarang. Hal ini dimulai pada abad ke-19 dimana kegiatan eksplorasi dan eksploitasi sudah dimulai dimana Pemerintah Belanda mengirimkan tim ekspedisinya yang dipimpin oleh Cornelis De Groot van Embden diberi misi untuk melakukan eksplorasi di wilayah jajahan untuk mencari potensi tambang khsusnya batu bara dan timah. Eksplorasi dilakukan di wilayah Pulau Bawen pada tahun 1850, Februari 1850 di Pulau Madura serta pada tahun 1851 di Belitung dan hasilnya sangat menggembirakan. Dengan hasil yang baik ini membuat kalangan untuk melakukan hal yang sama sebut saja dari era Aeilko Jans Zijlkera pada tahun 1883, tahun 1887 di Jawa Timur oleh Adriaan Stoop, di Kalimantan dimulai oleh Jaco-bus Hubertus pada tahun 1888, kemudian pada tahun 1890 gantian Jean Baptist Au-gust membangun kilang minyak, di Sumatera Selatan pencarian minyak bumi diawali oleh Dominicus Antonius Josephin Kessler dan Jan Willem Ijzerman pada tahun 1895 melalui perusahaannya bernama Nederlandsche Indische Exploratie Maatschappij (NIEM), sebagian dari mereka membuahkan hasil yang bagus dan banyak diantara mereka bahkan mendirikan perusahan-perusahan yang bergerak dalam bidang minyak dan gas bumi. Sebenarnya karena banyak muncul perusahaan tersebut dibuatkanlah undang-undang pertambangan yang disebut Indische Mijnwet (IMW) pada masa itu bertujuan untuk mengatur usahausaha pertambangan termasuk pertambangan minyak di Hindia Belanda.

Selama dijajah oleh bangsa lain, Bangsa Indonesia selalu dalam cengkraman bangsa penjajah sehingga belum dapat menentukan nasibnya sendiri termasuk di dalam permasalahan pertambangan serta migas, tepat pada tanggal 17 Agustus 1945 Bangsa Indonesia memproklamirkan kemerdekaannya dimana para pejuang pada saat itu mengupayakan peralihan kepemilikan perusahan minyak peninggalan Hindia Belanda yang bertujuan untuk kepentingan bangsa dan rakyat Indonesia. Untuk mewujudkan hal itu Bangsa Indonesia membentuk Perusahaan Tambang Minyak Nasional Rakyat Indonesia (PTMNRI) kemudian pada tahun 1946 membentuk Perusahaan Minyak Republik Indonesia (PERMIRI) yang bertujuan mengambil alih kilang-kilang minyak bekas Stanvac di Talang Akar. Setelah kemerdekaan Republik Indonesia pemerintahan pada saat itu 
melakukan perubahan besar berkenaan dengan peraturan undang-undang tentang pertambangan dan migas dimana aturan yang ada pada saat itu adalah peninggalan penjajahan yaitu Indische Minjwet (IMW).(7)

\section{Pengelolaan Sumber Daya Alam Indonesia}

Penguasaan dan pengelolaan migas, batu bara dan sumber kekayaan alam lainnya telah diatur dalam UUD 1945 dan Undang-Undang RI No.4 Tahun 2009 tentang mineral dan batu bara bahwa pengelolaannya harus berpedoman pada asas-asas: (1) manfaat, keadilan dan keseimbangan; (2) keberpihakan kepada kepentingan bangsa; (3) partisipatif, transparansi dan akuntabilitas; dan (4) berkelanjutan dan berwawasan lingkungan. Namun, pada kenyataannya dalam pengelolaan migas dan batu bara masih sering terjadi konflik antara masyarakat dan pengusaha di daerah, serta pemanfaatan dan pengelolaannya yang tidak mengindahkan kepentingan kelestarian lingkungan dan kepentingan masyarakat lokal. Pengelolaan migas dan batu bara implementasinya masih hanya berorientasi kepada kepentingan penerimaan/pendapatan Negara, belum sepenuhnya tertuju kepada kesejahteraan rakyat.(8)

Pengelolaan sumber kekayaan alam migas dan batu bara di Indonesia saat ini belum kompetitif, produk migas dan batu bara masih diekspor dalam bentuk bahan mentah (raw material) sehingga forward linkage-nya pendek dan multiplier effect-nya kecil. Hal ini berpengaruh terhadap manfaat yang dirasakan langsung masyarakat dalam bentuk kesejahteraan. Eksploitasi sumber daya alam saat ini, juga tidak memperhatikan aspek keberlanjutan dan kelestarian lingkungan. Tingkat produksi migas dan batu bara dilakukan secara berlebihan tanpa memperhatikan peruntukan masa depan sehingga tidak menjamin keberlanjutan pembangunan nasional di masa yang akan datang.(8)

Semenjak Indonesia merdeka hingga saat ini persoalan pengelolaan migas masih menyimpan beberapa catatan penting yang harus segera diselesaikan dan dicarikan jalan keluarnya. Pertama, berkenaan dengan inkonsisten dan lemahnya regulasi, Indonesia belum memiliki regulasi migas yang permanen, sistematis, komprehensip dan stabil malah sebaliknya yang ada justru sebaliknya, lemah, labil dan tumpang tindih hal ini tidak sejalan dan seiring dengan citacita bangsa Indonesia yang tertuang di dalam konstitusi. Kedua, tentang Kolusi, Korupsi dan Nepotisme (KKN). Berdasarkan data yang dikumpulkan melalui penelitian LP3ES bisnis migas di Indonesia rawan akan kebocoran, korupsi dan intervensi kekuasaan hal ini berkaitan dengan nilai bisnis hingga ribuan triliun rupiah. Ketiga, lemahnya goodwill dan mental mandiri, Indonesia masih lemah di dalam modal dan keahlian dalam bidang migas, kelemahan modal dan keahlian ini bisa dilihat setelah habisnya masa kontrak antara kontraktor dengan pemerintah sebagai pemilik tambang dimana pemerintah tidak berusaha keras untuk menguasai sendiri tambang-tambang yang potensial di saat habisnya masa kontrak justru hal itu kembali diberikan kepada kontraktor dengan alasan kemampuan teknis.(7)

Dengan melihat kondisi seperti diatas tentu tidak akan menguntungan bagi pemerintah Indonesia sendiri sebab masih bergantungan dengan investor asing serta kontraktor-kontraktor asing dengan begitu negara Indonesia dengan sangat mudah akan terus ditunggangi oleh kepentingan pelaku bisnis yang didominasi oleh perusahaan asing. Maka dari itu bangsa ini harus keluar dari permasalahan-permasalahan tersebut untuk dapat mandiri serta berdiri sendiri di dalam pengelolaan migas di negeri sendiri tujuannya ialah untuk menciptakan keadilan sosial bagi seluruh rakyat Indonesia.

\section{Metodologi Penelitian}

Penelitian ini menggunakan metode fenomenologi, karena penelitian ini bertujuan untuk mengamati peristiwa nyata yang terjadi pada implementasi kebijakan pemerintah pada pengelolaan sumber daya alam (natural resources), khusus pada industri minyak bumi dan gas alam (migas) di Madura, Jawa Timur. Pada saat yang sama, memotret bagaimana pengelolaan kebijakan terhadap pengembangan sumber daya manusia (human resources development) yang ada di Madura.

Hal yang diamati dalam penelitian ini adalah terkait dengan data dan fakta yang ditemukan dalam implementasi kebijakan 
migas dan pemberdayaan SDM di Madura, Jawa Timur. Di antaranya apa saja upaya yang dilakukan oleh pemerintah terhadap SDM di Madura yang memiliki kekayaan alam khususnya migas yang melimpah. Dengan demikian, penelitian ini menyediakan gambaran yang relatif lengkap mengenai apa yang terjadi pada saat penelitian dilakukan.

Sementara itu, desain penelitian (research design) yang dipilih dalam penelitian ini adalah pendekatan kualitatif deskriptif. Dengan demikian, penelitian ini dilakukan melalui pengamatan langsung terhadap objek pada saat penelitian dilakukan dengan menggunakan observasi dan wawancara kepada para pihak terkait baik dari sisi pemerintah, dalam hal ini bagian ESDM, maupun kontaktor kontrak kerjasama (KKKS) perusahaan migas yang beroperasi di wilayah Madura, Jawa Timur. Pihak masyarakat, dan akademisi yang mengetahui persoalan migas di Madura.

Fokus penelitian ini adalah aturan/regulasi dan implementasi kebijakan pemerintah terhadap pengelolaan migas dan pemberdayaan masyarakat, terutama masyarakat yang lokasi tempat tinggalnya berdekatan dengan kegiatan eksplorasi dan produksi migas di Madura, Jawa Timur. Bagaimana upaya dan bentuk pemberdayaan yang dilakukan oleh pemerintah maupun perusahaan, dan bagaiaman peran program tersebut dalam meningkatkan sumber daya manusia (SDM) di Madura, Jawa Timur.

Pengumpulan data dilakukan dengan cara observasi yang dilakukan langsung oleh peneliti, untuk melihat aktivitas dan kehidupan warga yang tinggal di lokasi kegiatan eksplorasi dan produksi migas. Selain melakukan observasi, peneliti juga melakukan wawancara langsung dengan informan kunci yang terdiri dari pihak perusahaan migas, tokoh masyarakat, tokoh pemuda, dan masyarakat secara umum. Selain terhadap informan kunci, wawancara juga dilakukan dengan pihak pemerintah, baik pemerintah desa, maupun kantor ESDM yang ada di Madura, Jawa Timur. Termasuk dengan Direktur Badan Usaha Milik Daerah (BUMD) yang bergerak di sektor migas. selain itu dilakukan juga upaya penelusuran dokumen dengan cara mencari data terkait dengan aturan dan regulasi yang mengatur bagaimana pengelolaan industri migas di Indonesia. Terutama terkait dengan dana bagi hasil (DBH) pusat dan daerah, besaran hak partisipasi atau Participating Interest (PI) dan ketentuan umum maupun khusus terkait migas. Selain itu, ditelusuri juga aturan terkait di daerah berupa Peraturan Daerah (Perda).

Data yang dikumpulkan di lapangan dilakukan pengecekan ulang, dengan melakukan verifikasi terhadap informan lain yang juga menjadi pihak yang berkaitan langsung dengan industri migas, dan program pemberdayaan di bidang ekonomi dan pendidikan pemerintah. Data yang diperoleh kemudian disusun dengan menggunakan teknik pengolahan data, mereduksi data, menyajikan data yang sudah diperoleh, dan menarik kesimpulan.

\section{Hasil dan Pembahasan}

Madura merupakan salah satu wilayah yang dikenal memiliki sumber daya alam (natural resources), terutama minyak alam dan gas bumi (migas). Dari empat kabupaten yang ada di Madura, yaitu Bangkalan, Sampang, Pamekasan dan Sumenep, hampir seluruhnya terdapat perusahaan migas yang melakukan kegiatan eksplorasi maupun produksi. hanya Kabupaten Pamekasan yang belum memiliki perusahaan migas yang melakukan kegiatan produksi, meski ada juga yang menyebut bahwa Kabupaten Pamekasan memiliki kandungan sumber daya alam, terutama migas.

Pulau Madura terbagi dalam empat wilayah kabupaten. Dengan luas wilayah untuk kabupaten Bangkalan 1.144,75 km terbagi dalam 8 wilayah kecamatan, kabupaten Sampang berluas wilayah 1.321,86 $\mathrm{km}$ terbagi dalam 12 kecamatan, kabupaten Pamekasan memiliki luas wilayah 844,19 km yang terbagi dalam 13 kecamatan, dan kabupaten Sumenep mempunyai luas $1.857,530 \mathrm{~km}$ terbagi dalam 27 kecamatan yang tersebar di wilayah daratan dan kepulauan.

Berdasarkan data SKK Migas, Lifting minyak Indonesia pada periode Januari-juni 2016 mencapai 817.900 barel per hari (bph). Sedangkan lifting gas 6.601,5 MMSCFD. Secara total, lifting migas di semester 1-2016 sebesar 1,122 juta barel setara minyak per hari (barel oil equivalent per day/boepd). Di 
antara hasil minyak tersebut, disumbangkan Blok Ketapang di lepas pantai kabupaten Sampang, pulau Madura, Provinsi Jawa Timur yang dioperasikan oleh Ketapang II Ltd, dimana produksinya mencapai 17.300 bph. Sedangkan penyumbang gas, disokong dari Blok Kangean di kabupaten Sumenep, Provinsi Jawa Timur yang dioperasikan oleh Kangean Energy Indonesia Ltd dengan produksi 39.000 boepd.(3)

Jumlah penduduk miskin di wilayah Madura yang merupakan daerah penghasil migas sangat tinggi. Seperti di Kabupaten Sampang yang merupakan daerah penghasil migas dengan dua perusahaan yang beroperasi yaitu PT Santos dan Husky CNOOC Madura Limited (HCML). Di Kabupaten Sampang jumlah penduduk miskinnya cukup besar yaitu $24 \%$ lebih atau sama dengan 227 ribu jiwa. Begitu pula dengan Kabupaten Bangkalan jumlah penduduk miskinnya mencapai $21 \%$ lebih, atau sama dengan 205 ribu jiwa. Padahal di Bangkalan terdapat perusahaan migas yaitu PT Pertamina Hulu Energi West Madura Offshore (PHE WMO). Hal yang sama juga terjadi di Kabupaten Sumenep. Di Sumenep jumlah penduduk miskin berjumlah 216 ribu jiwa, atau sama dengan $20 \%$ lebih dari total penduduk yang tersebar di 27 kecamatan yang terdiri dari wilayah daratan dan kepulauan.

Menariknya, untuk kabupaten yang bukan merupakan daerah penghasil migas seperti Kabupaten Pamekasan, jumlah penduduk miskin paling kecil di Madura, dalam hitungan jumlah maupun persentase. Jumlah penduduk miskin di Pamekasan sebanyak 142 ribu jiwa, dari jumlah total penduduk Kabupaten Pamekasan sebanyak 853 ribu jiwa atau, sama dengan $16,7 \%$. Jumlah tersebut lebih rendah dari pada jumlah penduduk miskin di tiga kabupaten lain di Madura yang notabene merupakan daerah penghasil migas, seperti Sumenep, Sampang dan Bangkalan.

Dari sisi pendidikan, terutama jika dilihat dari indeks pembangunan manusia (IPM), kondisi kabupaten yang menjadi penghasil migas juga tidak lebih baik daripada kabupaten yang bukan penghasil migas. Kabupaten Sampang yang menjadi daerah penghasil migas IPM-nya berada di angka
59.09. Yang sama juga terjadi pada Kabupaten Bangkalan dengan IPM 62.06, dan Kabupaten Sumenep 63.42. Angka IPM di tiga kabupaten penghasil migas tersebut lebih rendah dari angka IPM Kabupaten Pamekasan yang bukan penghasil migas, yaitu 63.98. Secara umum, indeks pembangunan manusia (IPM) kabupaten di Madura jauh berada di bawah indeks pembangunan manusia (IPM) Jawa Timur sebesar 69.74. sekali lagi, dari empat kabupaten yang ada di Madura, yang tinggi dan paling mendekati IPM Jawa Timur adalah Kabupaten Pamekasan, yang merupakan kabupaten bukan penghasil migas. Sementara tiga kabupaten lain, yaitu Sampang, Bangkalan, dan Sumenep yang merupakan kabupaten penghasil migas, berada di posisi jauh tertinggal dari sisi indeks pembangunan manusia (IPM).

Jika dilihat pada tingkat pendidikan atau lama sekolah, maka kabupaten daerah penghasil migas di Madura juga tidak lebih kondisinya dibandingkan dengan daerah yang bukan penghasil migas di Madura. Di Kabupaten Sampang, sebagai salah satu daerah penghasil migas di Madura, tingkat pendidikan rata-rata tidak lulus sekolah dasar (SD) atau rata-rata lama penduduknya bersekolah hanya empat tahun. Begitu pula dengan kabupaten lain yaitu Kabupaten Bangkalan dan Kabupaten Sumenep rata-rata lama penduduk bersekolah adalah lima tahun, atau sama dengan tidak lulus sekolah dasar (SD). Kondisi tersebut lebih rendah dari tingkat pendidikan di Kabupaten Pamekasan yang termasuk bukan daerah penghasil migas. Di Pamekasan, rata-rata penduduknya sudah lulus sekolah dasar (SD) atau sama dengan bersekolah enam tahun lebih. Meski tetap masih minim, namun pendidikan di Pamekasan lebih baik dari tiga kabupaten lain yang merupakan kabupaten penghasil migas di Madura.

Kurang berhasilnya pendidikan dan peningkatan taraf hidup atau perekonomian warga yang berada di wilayah penghasil sumber kekayaan alam, sesungguhnya berkorelasi dengan apa yang telah dikemukakan oleh ahli, terkait dengan teori kutukan (curse theory). Secara lebih ekstrim, dikemukakan oleh teori kutukan, bahwa daerah/negara yang memiliki sumber daya alam (natural resources), kondisi negara tersebut tidak lebih baik dari negara lain, 
bahkan dari negara yang tidak memiliki sumber kekayaan alam sekalipun.

Kutukan sumber daya alam yang terjadi di Indonesia diduga terjadi setelah era desentralisasi dan otonomi daerah. Banyak kabupaten/kota yang mendapatkan penerimaan sumber daya alam mengalami pertumbuhan Produk Domestik Regional Bruto (PDRB) yang rendah, tingginya angka kemiskinan, serta rendahnya kualitas sumber daya manusia (IPM). Kualitas sumber daya manusia yang diproksikan oleh indeks pembangunan manusia (IPM) menjelaskan mengapa Dana Bagi Hasil (DBH)-SDA tidak mendorong pertumbuhan ekonomi. Semakin tinggi DBH-SDA, maka semakin rendah IPM nya. Selanjutnya, pemerintah daerah yang mendapatkan DBH-SDA paling tinggi memiliki kinerja pemerintahan yang buruk sejalan dengan terjadinya peningkatan DBHSDA tersebut.

Indonesia dipandang mampu keluar dari kutukan sumber daya alam pada level nasional. Temuan empiris menunjukkan bahwa Indonesia dan Nigeria merupakan dua Negara yang memiliki pendapatan per kapita yang sama dan sama-sama bergantung pada penjualan minyak. Namun demikian, kini pendapatan per kapita Indonesia menjadi empat kali lebih tinggi dibanding Nigeria.(4)

Pada kasus Madura, beberapa indikator yang disebut ahli tersebut juga menemukan fakta empiris. Meski tidak secara keseluruhan sama persis, ada sejumlah temuan yang bisa jadi berkolerasi dengan apa yang dikemukakan ahli tersebut. Misalnya dalam kasus korupsi, ada dua daerah di Madura yang pejabatnya terbelit kasus korupsi di bidang migas. Di Bangkalan kasus korupsi terkait migas membelit Ketua DPRD Bangkalan yang juga mantan Bupati Bangkalan Fuad Amin. Sementara di Sumenep, kasus korupsi di sektor migas juga membelit mantan direktur PT Wira Usaha Sumekar (WUS) Sitrul Arsyh.

Bekas Bupati Bangkalan Fuad Amin Imron mengaku menerima duit suap dari Direktur Human Resource Development PT Media Karya Sentosa (PT MKS) Antonius Bambang Djatmiko. Fuad mengatakan duit suap diberikan empat kali dalam empat bulan pada tahun 2013. Dua bulan diterimanya saat ia menjabat sebagai bupati dan dua bulan lainnya saat ia purna tugas. Fuad menerangkan uang tersebut adalah "uang sagu hati" yang diartikan Fuad sebagai ucapan terima kasih dari Bambang atas bantuan Fuad memuluskan jual beli gas alam di Blok Poleng, Bangkalan, Madura. Dalih lainnya, uang merupakan duit kompensasi yang diberikan ke Badan Usaha Milik Daerah setempat, PD Sumber Daya. Kompensasi didapat dari kesepakatan dengan PT MKS. Atas kasus tersebut, Mahkamah Agung (MA) menjatuhkan vonis 13 tahun penjara pada mantan Bupati Bangkalan Fuad Amin Imron atau lebih ringan dari tuntutan Jaksa Penuntut KPK. Namun, Fuad kehilangan hak politiknya dan disita harta bendanya serta didenda Rp 5 miliar.(2)

Kejaksaan Tinggi (Kejati) Jawa Timur menetapkan direktur utama badan usaha milik daerah (BUMD) PT Wira Usaha Sumekar (WUS) periode 2011-2015 Sitrul Arsy Musa'ie sebagai tersangka. Penyidik Kejati Jawa Timur mendatangkan dua orang dalam pemeriksaan sebelum akhirnya memutuskan untuk menahan Sitrul. Menurut Kasi Penerangan Hukum (Kasipenkum) Kejati Jawa Timur Richard Marpaung penahanan dilakukan untuk memperlancar penyidikan. Waktu penahanan bisa diperpanjang penyidik selama masa penyidikan. Penahanan dilakukan setelah semua bukti keterlibatan kasus PT WUS soal dana Participating Interest (PI) lengkap. PT WUS mendapat PI 10 persen sebagai bagian hasil pengelolaan migas di wilayah Sumenep dari PT Santos Madura Offshore. Dalam rangka menerima PI, Sitrul diduga membuka kantor perwakilan di Jakarta. Secara pribadi juga membuka rekening bank bentuk rupiah dan dolar Amerika untuk menampung PI. Pembukaan rekening ini tanpa sepengetahuan Pemkab sumenep. Uang yang masuk sebesar USD 773.702,84 dari PI. Kemudian yang digunakan Sitrul Rp 3.995.852.217. Dengan demikian, merugikan negara sesuai temuan BPK sebesar Rp 3.995.852.217. Dugaan penyimpangan dana PT WUS dari dana PI sebagai pembagian dari PT PPM selama 2009 sampai 31 Agustus 2015. Perusahaan itu memperoleh pendapatan USD 1.687.642,53 dan Rp 934.953.250,00. Pendapatan sebelumnya (past revenue) USD 600.144,31 dan pendapatan PI sebesar Rp USD 1.087.498.22. Atas perbuatannya, tersangka 
dijerat dengan pasal 2 subsider pasal $3 \mathrm{UU}$ 31/ 1999 tentang Pemberantasan Tindak Pidana Korupsi. Dia terancam hukuman di atas lima tahun penjara. Kemelut di PT WUS terungkap setelah adanya laporan hasil pemeriksaan (LHP) Badan Pemeriksa Keuangan (BPK) pada Agustus 2016. Pendapatan PI pada Blok Madura Offshore dari PT PPM tidak dilaporkan dalam laporan keuangan PT WUS.(6)

Selain persoalan korupsi, ada beragam persoalan lain yang menjadi batu sumbatan (bottleneck) teruainya persoalan migas di Madura. Jika dirinci sesungguhnya persoalan tidak tunggal, tapi sangat beragam dan menyangkut berbagai dimensi, baik pusat, propinsi maupun kabupaten. Sehingga menjadi persoalan akumulatif.

Negara sebetulnya memiliki perangkat yang memadai untuk memberi penguatan dan keberpihakan (affirmative action) terhadap daerah penghasil migas. Salah satu celahnya adalah dengan memaksimalkan aturan dan ketentuan yang terkait dengan tanggung jawab sosial perusahaan atau corporate social responsibility (CSR). CSR bisa menjadi ujung tombak peningkatan mutu sumber daya manusia (human resources) bagi daerah yang menjadi penghasil migas.

Pelaksanaan tanggung jawab sosial perusahaan atau corporate social responsibility (CSR) di Indonesia sendiri sudah diatur dalam UU No. 40 Tahun 2007 tentang Perseroan Terbatas. Dalam undangundang ini diatur mengenai tanggung jawab sosial dan lingkungan yang bertujuan mewujudkan pembangunan ekonomi berkelanjutan guna meningkatkan kualitas kehidupan dan lingkungan yang bermanfaat bagi perseroan itu sendiri, komunitas setempat, dan masyarakat umumnya.(5)

Selain itu dalam Pasal 33 ayat (2) dan (3) UUD 1945 dikatakan bahwa Negara memiliki kekuasaan penuh untuk mengelola sumber daya alam di bumi Indonesia. Terlebih lagi migas termasuk dalam kategori sumber daya alam vital yang menjadi hajat hidup rakyat, sedangkan proses pengelolaannya atau produksinya masuk dalam kategori cabang produksi yang dilakukan untuk memenuhi hajat hidup rakyat. Presiden Joko Widodo dalam suatu kesempatan mengingatkan bahwa amanat konstitusi harus betul-betul diperhatikan karena dengan tegas dan jelas menyatakan bumi dan air serta kekayaan yang terkandung didalamnya dikuasai oleh Negara dan dipergunakan untuk sebesar-besarnya kemakmuran rakyat. Dipergunakan untuk sebesar-besarnya kemakmuran rakyat, itu mengandung arti bahwa apa yang dihasilkan dalam pemanfaatan sumber daya alam itu harus benar-benar untuk rakyat untuk semua masyarakat Indonesia untuk semua orang dan bukan untuk segelintir atau sekelompok orang.(10)

Jika dilihat dari kondisi ekonomi dan pendidikan masyarakat Madura seperti yang digambarkan pada uraian sebelumnya, maka tanggung jawab sosial perusahaan atau corporate social responsibility (CSR) perlu lebih diarahkan/difokuskan pada sektor ekonomi dan pendidikan. Paradigma ini akan semakin memacu perusahaan untuk menjadikan CSR sebagai investasi, bukan lagi sekadar kewajiban. Sebagai sebuah investasi, investasi sosial yang selanjutnya akan dirasakan dampaknya oleh perusahaan migas. Hal ini sesuai tujuan Pasal 33 UndangUndang Dasar 1945 yang menyebut bahwa penguasaan negara terhadap kekayaan alam adalah untuk sebesar-besarnya kemakmuran rakyat.(9)

Salah satu contoh yang terjadi di Bojonegoro, Jawa Timur. Di Bojonegoro kontribusi sektor migas terhadap daerah sangatlah besar, baik yang melalui pemerintah daerah dengan kebijakan dan perencanaan daerah maupun langsung dari perusahaan terkait yang bergerak di bidang migas. Melalui program CSR perusahaan juga turut berkontribusi dalam pembangunan daerah. Proses pelaksanaan CSR sendiri langsung dilakukan dan menjadi tanggungjawab penuh perusahaan terkait. Bentuk kegiatan beragam, mulai dari peningkatan pendidikan, kesehatan, sosial dan lain-lain. Semua kegiatan tersebut adalah salah satu tanggungjawab perusahaan atas keberadaannya di lingkungan masyarakat sekitar. Program CSR tersebut terbukti telah berkontribusi cukup besar terhadap perkembangan dan pertumbuhan pembangunan di area industri migas.(1)

Perusahaan migas di Madura sebetulnya sudah memberi perhatian terhadap sektor pendidikan, hanya saja, volumenya perlu 
ditingkatkan secara signifikan. Salah satunya yang dilakukan oleh PT. Kangean Energi Indonesia Ltd (KEI) yang beroperasi di Kabupaten Sumenep. Melalui program pendukung operasi (PPO) perusahaan menjalankan program CSR meliputi berbagai bidang, pendidikan, kesehatan, ekonomi, lingkungan dan infrastruktur. Untuk bidang pendidikan, pada tahun 2015, PT. KEI telah memberikan bantuan beasiswa bagi siswa SMA dan mahasiswa sebanyak 49 orang, di antaranya siswa SMA sebanyak 23 orang dan mahasiswa sebanyak 26 orang, itupun pada angkatan tahun 2012/2013 untuk siswa SMA, sedangkan untuk mahasiswa merupakan angkatan tahun 2013/2014. Siswa angkatan 2014/2015 sebanyak 27 orang, dan untuk angkatan tahun ajaran 2015/2016 sebanyak 40 orang. Bahkan beasiswa lainnya ditujukan untuk perguruan tinggi yang diberikan dari semester pertama hingga lulus perguruan tinggi (AKAMIGAS), yang mana pada tahun 2015 mahasiswa tersebut telah lulus dan menyelesaikan studinya.

Selain beasiswa, guru non PNS (Pegawai Negeri Sipil) dari tingkat sekolah dasar dan sekolah menengah juga menjadi perhatian dengan diberi tunjangan insentif masingmasing guru dihitung berdasarkan frekuensi mengajar dengan besaran tunjangan berkisar antara Rp. 250.000-Rp. 380.000 per tiga bulan. Tunjangan intensif bagi guru tersebut menyebar di berbagai lembaga yang ada di Kecamatan Sapeken, di antaranya, Desa Pagerungan Besar, sebanyak 40 guru yang terdiri dari 9 sekolah dari tingkat dasar hingga menengah pertama, untuk Desa Pagerungan Kecil, sebanyak 40 guru terdiri dari 10 sekolah tingkat dasar hingga menengah pertama. Sedangkan yang terakhir yaitu, Desa Sepanjang dengan jumlah sebanyak 40 guru dari 10 sekolah tingkat dasar hingga menengah pertama.

\section{Kesimpulan}

Kekayaan alam berupa migas di Madura, yang sudah diproduksi, sekalipun tidak selalu berdampak positif terhadap peningkatan taraf hidup perekonomian warga dan pengembangan sumber daya manusia (SDM) secara umum, seperti yang dialami oleh warga yang berada di wilayah produksi migas. Untuk melihat dampak negatif yang ditimbulkan oleh penyelewengan sumber daya alam, diperlukan strategi sebagai berikut. Pertama, mengurangi ketergantungan terhadap sumber daya alam, serta meningkatkan pendapatan yang bersumber selain sumber daya alam. Kedua, pengembangan kualitas sumber daya manusia yang berfokus pada kesehatan dan pendidikan. Hal ini dapat dilakukan melalui kebijakan yang mengalokasikan penerimaan sumber daya alam pada kedua sektor tersebut dalam rangka memajukan perekonomian daerah dan meningkatkan kesejahteraan masyarakat dalam jangka panjang.

\section{Daftar Pustaka}

1. Adhitama O. Kontribusi Sektor Migas Terhadap Penerimaan Daerah Dalam Rangka Meningkatkan Pembangunan Daerah Di Kabupaten Bojonegoro. Jurnal Administrasi Publik Mahasiswa Universitas Brawijaya 2: 492-498, 2014.

2. Adzkia A. Eks Bupati Bangkalan Fuad Amin Akui Terima Suap Bos Migas [Online]. $C N N$ Indonesia: [date unknown]. https://www.cnnindonesia.com/nasional/2015 0917113744-12-79322/eks-bupati-bangkalanfuad-amin-akui-terima-suap-bos-migas $\quad$ [22 Mar. 2018].

3. Andri. Madura 'Duduk' di Atas Ladang Migas [Online]. siagaindonesia.com - Situs Berita Siaga Indonesia: [date unknown]. http://www.siagaindonesia.com/143055/mad ura-duduk-di-atas-ladang-migas.html [22 Mar. 2018].

4. Artikel I. Kutukan Sumber Daya Alam di Indonesia. .

5. Gunawan MIP, Lubis AT. Pengungkapan Corporate Social Responsibility Bidang Pendidikan Dalam Laporan Tahunan Bank Umum Syariah Di Indonesia [Online]. 14 , 2016.

http://jurnal.sebi.ac.id/index.php/jaki/article/v iew/57 [22 Mar. 2018].

6. JawaPos.com. Kejati Jatim Tahan Mantan Dirut PT WUS [Online]. [date unknown]. https://www.jawapos.com/radarmadura/read/ 2017/10/14/19652/kejati-jatim-tahan-mantandirut-pt-wus [22 Mar. 2018].

7. Mangku DGS. Migas Untuk Rakyat (Catatan Seorang Praktisi) [Online]. Jurnal Hukum Novelty 7, 2016. http://journal.uad.ac.id/index.php/Novelty/art icle/view/3939 [21 Mar. 2018].

8. M.S DIHR. Pengelolaan Migas dan Batu Bara Yang Kompetitif: Guna Meningkatkan 
Kesejahteraan Rakyat dalam Rangka Pembangunan Nasional. Yogyakarta: Penerbit Andi, [date unknown].

9. Roziqin. Pengelolaan sektor minyak bumi di indonesia pasca reformasi: analisis konsep negara kesejahteraan. Jurnal Tata Kelola \& Akuntabilitas Keuangan Negara 1: 128-140, 2015.

10. Setiawan J. Partisipasi Daerah Penghasil (Participating Interest) Di Wilayah Kerja (Blok) Masela [Online]. Jurnal Komunikasi Hukum (JKH) 2, 2016. https://ejournal.undiksha.ac.id/index.php/jkh/ article/view/8413 [20 Mar. 2018].
11. Taufik GA. Sumber Daya Alam Indonesia: Kutukan yang Mewujud? [Online]. PSHK Pusat Studi Hukum dan Kebijakan Indonesia: $2014 . \quad$ http://www.pshk.or.id/id/blogid/sumber-daya-alam-indonesia-kutukanyang-mewujud/ [20 Mar. 2018].

12. Putusan Mahkamah Konstitusi [Online]. http://www.mahkamahkonstitusi.go.id/public /content/persidangan/putusan/34_PUUXV_2017. [20 Mar. 2018]. 